\title{
Effect of Small Transverse Service Holes on Shear Strength of Reinforced Concrete Slender Beams
}

\section{*OLANITORI, LM; TIFASE, TO}

\author{
Department of Civil Engineering, Federal University of Technology, Akure, Ondo State, Nigeria. \\ *Corresponding Author Email: lekanolanitori@gmail.com; other author email: tifasholadayo@yahoo.com
}

\begin{abstract}
This paper presents the results of a study conducted to investigate the effect of small transverse hole on the shear capacity of slender beams. A total number of ten beams were cast, with concrete grade of C13.02. The cross -sectional dimensions of the beams were $100 \mathrm{~mm} \times 150 \mathrm{~mm}$, with an effective span of $560 \mathrm{~mm}$. The tested beams consisted of two control beams. The experimental beams consisted of eight beams, four of the beams were with $20 \mathrm{~mm}$ service hole (two beams with holes at the centre and two beams with holes at $220 \mathrm{~mm}$ from both ends), while the other four had $25 \mathrm{~mm}$ service holes, with two of beams had holes at the centre, while the other two beams had holes at $220 \mathrm{~mm}$ from both ends. The beams were subjected to both point load and load at third points. The study shows that the ultimate load of beams with service holes depends on the size of holes, position of holes, and of type loading.
\end{abstract}

\section{DOI: https://dx.doi.org/10.4314/jasem.v23i3.25}

Copyright: Copyright $($ C 2019 Olanitori and Tifase. This is an open access article distributed under the Creative Commons Attribution License (CCL), which permits unrestricted use, distribution, and reproduction in any medium, provided the original work is properly cited.

Dates: Received: 17 November 2018; Revised: 19 January 2019; Accepted 22 January 2019

Keywords: Slender beam, Concrete, Compressive strength, Control beam, Service hole

From a practical point of view, openings in concrete members are means of accommodating utility services in building structure. Usually, these pipes and ducts are placed underneath the beam soffit and, for aesthetic reasons, are covered by a suspended ceiling, thus creating a dead space. Passing these ducts through transverse openings in the floor beams instead of below or above the member leads to a reduction in the dead space and results in a more compact design (Mansur et al., 1985). For small buildings, the savings thus achieved may not be significant. But for multistorey buildings, any saving in storey height multiplied by the number of stories can represent a substantial saving in materials and man hour. All these translate to reduction in the sizes of structural members of reinforced concrete structures, which in turn, reduces the amount of cement needed for construction, this is accompanied by reduction in $\mathrm{CO}_{2}$ emission associated with the production of cement: this will have reduction effect on the greenhouse, a major cause of climate change. The web openings of the beam result in the decrease of flexural stiffness, flexural and shear strengths, increase in the deflection of the beam and may lead to cracking. Therefore the reinforcement at the openings is needed to ensure the proper strength and stiffness of the beams (Mansur et al, 2006, Mansur and Tan, 1999a, Vivek, and Madhavi, 2016). Euro Code 2 (BS EN 1992-1-1, 2004) defines a deep beam as a member whose span is less or equal to 3 times the overall section depth. Hence slender beam can be said to be beam whose span is greater than 3 times the overall section depth. Beams with small and large openings need separate treatments in design (Mansur and Tan, 1999b). Mansur and Tan (1999b), considered circular and square (or rectangular) in shape opening as small if $d \leq 0.25 h$ (where $d$ is depth of square or rectangular openings or the diameter of a circular opening) and otherwise, it is classified as large opening. Therefore, analysis and design of a beam with small openings may follow the similar course of action as that of a solid beam. Mansur et al., (2006,), noted that the results of the Strut and Tie Model (STM) analysis of reinforced concrete deep beams with transverse circular opening in the web, show good agreement with experimental results. Mohamed et al (2014), shows that web openings crossing the expected compression struts should be avoided, and the depth of the opening should not exceed $20 \%$ of the beam overall depth and that reinforcement distribution should be in the range of $0.1-0.2$ beam depth for simply supported deep beams. For deep beams with opening, the ultimate strengths were decreased by $12 \%, 22 \%$ and $41 \%$ for beams containing opening at distance $\mathrm{L} / 2, \mathrm{~L} / 3$ and $\mathrm{L} / 6$ from the edge respectively (Aziz, 2016).

The simplified version of the expression to determine the shear strength of concrete (ACI 318, 2008) is presented as Eq. 1. 


$$
V_{c}=\frac{1}{6} \sqrt{f_{c}^{1}} b_{w} d
$$

Where $V_{c}$ is the nominal shear strength provided by concrete; $f_{c}^{1}$ is the concrete strength; $b_{w}$ is the web width; $d$ is the effective depth of section.

To include the effects of loading type and shear span to depth ratio into current code provisions, Brown et al (2006), proposes:

$$
V_{c}=\frac{1}{12} \sqrt{f_{c}^{1}} b_{w} d
$$

According to Arslan (2008), the nominal shear strength provided by concrete can be estimated using Eq. 3.

$$
\begin{aligned}
V_{c r}=V_{c r t}+ & V_{c r d} \\
& =0.15\left(f_{c}\right)^{0.5} b_{w} d \\
& +0.02\left(f_{c}\right)^{0.65} b_{w} d
\end{aligned}
$$

Where: $V_{c r}$ is the cracking shear strength, $V_{c r t}$ is the diagonal tension cracking strength, $V_{c r d}$ is the dowel strength and $f_{c}$ the concrete strength.

Shear strength models for diagonal cracking strength of RC slender beams without stirrups were by proposed by Kim and Park (1996), Rebeiz (1999) Khuntia and Stojadinovic (2001) Arslan (2012). Also in their work, Arslan and Polat (2013), showed that there exists a significant amount of contribution of concrete to the shear strength (18 - 69\%), however, noted further experiments should be conducted with a wider range of shear reinforcement ratio, shear spanto-depth ratio, concrete strength and various loading schemes in order to obtain more reliable assessments.

Since the mid-1980s, there is an increasing amount of experimental evidence showing that the underlying concepts of the provisions of current codes (for example, BS EN 1992-1-1, (2004) and ACI 318, (2008)) for the shear in particular and, to a certain extent for the flexural design of reinforced concrete (RC) structures are in conflict with fundamental properties of concrete at both the material and the structural levels (Kotsovs, 2007). Olanitori and Tifase (2017), noted that the decreasing effect of size of hole at the centre on the ultimate load of slender beam loaded at centre is $39.62 \%$ to $42.64 \%$, while that loaded at third points is $9.0 \%$ to $14.67 \%$. The tension reinforcements in reinforced concrete sections did not contribute as much to shear resistance of reinforced concrete sections as predicted by BS EN 1992-1-1 (2004), thereby confirming the assertion of Kotsovos (2007), that dowel action of the reinforcing steel has little part to play in the shear resistance (Olanitori at $e l, 2014$, Olanitori and Afolayan, 2014).

Based on the results of their research work Olanitori at el (2014), suggested that in order to reduce the failure of reinforced concrete space framed structures with beam-column joints hinged, that Eq. (4) can be used in the prediction of the shear capacity.

$\mathrm{V}=\lambda_{\mathrm{c}} \mathrm{V}_{\mathrm{c}}$

Where: $\lambda_{c}$ is the concrete shear capacity factor, $\mathrm{V}$ is the shear capacity of the space frame and, $V_{c}$ is the shear capacity due to concrete.

From ACI 318-08 (2008), design shear strength is calculated using Eq. (5).

$$
V_{n}=V_{c}+V_{s}=\frac{\sqrt{f_{c}}}{6} b_{w} d+\frac{A_{w} f_{y} d}{s}
$$

Olanitori at el (2016), suggested that for reinforced concrete space framed structures with beam-column joints rigid, that Eq. (6) can be used in the prediction of the shear capacity.

$$
\mathrm{V}=\lambda_{\mathrm{s}} \mathrm{V}_{\mathrm{s}}+\lambda_{\mathrm{c}} \mathrm{V}_{\mathrm{c}}=0.23 \mathrm{~V}_{\mathrm{s}}+0.7 \mathrm{~V}_{\mathrm{c}}
$$

Where: $\lambda_{\mathrm{s}}$ is the tension reinforcement and stirrups shear capacity factor.

\section{MATERIALS AND METHODS}

The materials used for this research work were Portland cement, sand $(4.75 \mathrm{~mm})$, crushed granite $(12 \mathrm{~mm})$, clean water and reinforcing bars. The concrete grade to be used was $13.02 \mathrm{~N} / \mathrm{mm}^{2}$, while that of reinforcing bar was $410 \mathrm{~N} / \mathrm{mm}^{2}$. Two numbers of beams were used as control beam (beam without holes), while the total number of experimental beams (beams with service holes) were eight. Four of these beams had $25 \mathrm{~mm}$ service holes (two of the beams have holes at the centre, while the other two had holes at $220 \mathrm{~mm}$ from both ends), while the other four had $20 \mathrm{~mm}$ service holes (with two of the beams have holes at the centre and the other two had holes at $220 \mathrm{~mm}$ from both ends). The beams specifications and materials strength characteristics are as given below:

Beam: $100 \mathrm{~mm} \times 150 \mathrm{~mm} \times 1000 \mathrm{~mm}$;

effective span $l_{e}=560 \mathrm{~mm} ; \mathrm{f}_{\mathrm{cu}}=13.02 \mathrm{~N} /$ $\mathrm{mm}^{2} ; \mathrm{f}_{\mathrm{y}}=410 \mathrm{~N} / \mathrm{mm}^{2} ; d=130 \mathrm{~mm}$;

Reinforcing bar $=2 \mathrm{Y} 10$; As $=157 \mathrm{~mm}^{2}$.

The beams were given two types of loadings: point loading and loading at third point. The point load was applied at the centre of the beam, while the second loading was a two symmetrical point load applied at $200 \mathrm{~mm}$ apart, and at a distance of $180 \mathrm{~mm}$ from the 
supports. The flexural tests carried out on the beams were in accordance with BS EN 12390-5 (2009).

\section{RESULTS AND DISCUSSION}

The estimated ultimate load was determined using the rectangular stress block of doubly reinforced rectangular section, while the shear capacity was determined using the equations of the BS EN 1992-11 (2004). These values are presented in Table 1.

Table 1: Estimated and actual strength characteristics of the control beams

\begin{tabular}{llllllll}
\hline Beam No & Load Position & \multicolumn{2}{c}{$\mathbf{M}_{\mathbf{R}}(\mathbf{k N m})$} & \multicolumn{3}{c}{$\mathbf{P}_{\mathbf{U L}}(\mathbf{k N})$} & \multicolumn{2}{c}{$\mathbf{V}_{\mathbf{S C}}(\mathbf{k N})$} \\
\hline & & $\mathbf{M}_{\mathbf{E R}}$ & $\mathbf{M}_{\text {AR }}$ & $\mathbf{P}_{\text {EUL }}$ & $\mathbf{P}_{\text {AUL }}$ & $\mathbf{V}_{\text {ESC }}$ & $\mathbf{V}_{\text {ASC }}$ \\
\hline B1 & beam Centre & 10.15 & & 72.5 & 68.00 & 91.33 & 34.00 \\
B2 & third points & 10.15 & & 113.28 & 75.00 & 91.33 & 37.50 \\
\hline
\end{tabular}

The results of the tests carried out on the beams are presented in Tables 1 to 5. Table 1 shows the estimated values of the moment and shear capacities of the control beams, as well as the results of the flexural tests carried out on them. From Table 1, the ultimate load was $68.0 \mathrm{kN}$ for the control beam loaded with point load at the centre, while the ultimate load for the one loaded at third points was $75.0 \mathrm{kN}$. This shows that the ultimate load of control beam loaded at third points is $10.29 \%$ greater than that loaded at centre. From Table 2, the ultimate load of experimental beam (B3) with $20 \mathrm{~mm}$ diameter holes at the centre and loaded at the centre was 42.1 $\mathrm{kN}$, while the one loaded at the third points (B4) was $47.15 \mathrm{kN}$. This shows that the ultimate load of the experimental beam loaded at the third points is $12 \%$ greater than one loaded with point load at the centre. Also for experimental beams B5 and B6, with $20 \mathrm{~mm}$ holes at the supports, but loaded at the centre and at point thirds, had ultimate loads of $62.5 \mathrm{kN}$ and $73.0 \mathrm{kN}$ respectively. This shows an increase of the ultimate load of beam loaded at third points over the loaded at the centre by $16.8 \%$.

Where: $M_{R}$ is the moment of resistance, $\mathrm{M}_{\mathrm{ER}}$ is the estimated moment of resistance, $\mathrm{M}_{\mathrm{AR}}-$ actual moment of resistance, $\mathrm{P}_{\mathrm{UL}}-$ ultimate load, $\mathrm{P}_{\mathrm{EUL}}$ is the estimated ultimate load, $\mathrm{P}_{\mathrm{AUL}}$ - actual ultimate load, $\mathrm{V}_{\mathrm{SC}}$ - shear capacity, $\mathrm{V}_{\mathrm{ESC}}$ is the estimated shear capacity, $\mathrm{V}_{\mathrm{ASC}}$ - actual shear capacity, B1 is the control beam loaded at centre and B2 is the control beam loaded at third points.

Table 2: Results of flexural test on Experimental Beams.

\begin{tabular}{|c|c|c|c|c|c|}
\hline $\begin{array}{l}\text { Beam } \\
\text { No }\end{array}$ & $\begin{array}{l}\text { Weight } \\
\text { (kg) }\end{array}$ & $\begin{array}{l}\text { Position } \\
\text { Of Hole }\end{array}$ & $\begin{array}{l}\text { Position Of } \\
\text { Load }\end{array}$ & $\begin{array}{l}\text { Load At } \\
\text { Failure }(k N)\end{array}$ & $\begin{array}{l}\text { Shear Force } \\
\text { V(kN) }\end{array}$ \\
\hline \multicolumn{6}{|c|}{ Beams with 20mm service holes } \\
\hline B3 & 43.50 & centre & beam centre & 42.10 & 21.05 \\
\hline B4 & 42.70 & centre & third points & 47.15 & 23.58 \\
\hline B5 & 44.20 & supports & beam centre & 62.50 & 31.25 \\
\hline B6 & 44.00 & supports & third points & 73.00 & 36.50 \\
\hline \multicolumn{6}{|c|}{ Beams with $25 \mathrm{~mm}$ service holes } \\
\hline B7 & 43.70 & centre & beam centre & 39.00 & 19.50 \\
\hline B8 & 43.50 & centre & third points & 48.25 & 24.13 \\
\hline B9 & 40.60 & supports & beam centre & 52.00 & 26.00 \\
\hline B 10 & 41.3 & supports & third points & 65.00 & 32.50 \\
\hline
\end{tabular}

Table 3: Comparison of estimated ultimate load and actual load of the experimental beams

\begin{tabular}{llll}
\hline $\begin{array}{l}\text { Beam } \\
\text { No }\end{array}$ & $\begin{array}{l}\text { Estimated Ultimate } \\
\text { Load }\left(\mathbf{F}_{\text {eul }}\right) \mathbf{K n}\end{array}$ & $\begin{array}{l}\text { Actual Ultimate Load } \\
\left(\mathbf{F}_{\text {aul }}\right) \mathbf{K n}\end{array}$ & $\left(\frac{\boldsymbol{F}_{\boldsymbol{E U L}}-\boldsymbol{F}_{\boldsymbol{A U L}}}{\boldsymbol{F}_{\boldsymbol{A U L}}}\right) \boldsymbol{x 1 0 0} \%$ \\
\hline $\mathrm{B}_{1}$ & 72.50 & 68.00 & 6.62 \\
$\mathrm{~B}_{2}$ & 113.28 & 75.00 & 51.04 \\
$\mathrm{~B}_{3}$ & 72.50 & 42.10 & 72.21 \\
$\mathrm{~B}_{4}$ & 113.28 & 47.15 & 140.25 \\
$\mathrm{~B}_{5}$ & 72.50 & 62.50 & 16.00 \\
$\mathrm{~B}_{6}$ & 113.28 & 73.00 & 55.18 \\
$\mathrm{~B}_{7}$ & 72.50 & 39.00 & 85.90 \\
$\mathrm{~B}_{8}$ & 113.28 & 48.25 & 134.78 \\
$\mathrm{~B}_{9}$ & 72.50 & 52.00 & 39.42 \\
$\mathrm{~B}_{10}$ & 113.28 & 65.00 & 74.28 \\
\hline
\end{tabular}

Table 4: Comparison of estimated shear and actual shear force of the experimental beams

\begin{tabular}{llll}
\hline $\begin{array}{l}\text { Beam } \\
\text { No }\end{array}$ & $\begin{array}{l}\text { Estimated Shear } \\
\text { Force }\left(\mathbf{V}_{\text {esf }}\right) \mathbf{K n}\end{array}$ & $\begin{array}{l}\text { Actual Ultimate } \\
\text { Shear Force } \\
\left(\mathbf{V}_{\text {ausf }}\right) \mathbf{K n}\end{array}$ & $\left(\frac{\boldsymbol{V}_{\boldsymbol{E S F}}-\boldsymbol{V}_{\boldsymbol{A U S} \boldsymbol{F}}}{\boldsymbol{V}_{\boldsymbol{A U S F}}}\right) \boldsymbol{x 1 0 0} \%$ \\
\hline $\mathrm{B}_{1}$ & 91.33 & 34.00 & 168.62 \\
$\mathrm{~B}_{2}$ & 91.33 & 37.50 & 143.55 \\
$\mathrm{~B}_{3}$ & 91.33 & 21.05 & 333.87 \\
$\mathrm{~B}_{4}$ & 91.33 & 23.58 & 287.32 \\
$\mathrm{~B}_{5}$ & 91.33 & 31.25 & 192.26 \\
$\mathrm{~B}_{6}$ & 91.33 & 36.50 & 150.22 \\
$\mathrm{~B}_{7}$ & 91.33 & 19.50 & 368.36 \\
$\mathrm{~B}_{8}$ & 91.33 & 24.13 & 278.49 \\
$\mathrm{~B}_{9}$ & 91.33 & 26.00 & 251.27 \\
$\mathrm{~B}_{10}$ & 91.33 & 32.50 & 181.02 \\
\hline
\end{tabular}

Also in Table 2, there are results of the flexural texts on the experimental beams with service holes of $25 \mathrm{~mm}$ diameter. The ultimate load of B7 with $25 \mathrm{~mm}$ diameter service holes at the centre and loaded at the centre was 39.0 $\mathrm{kN}$, while that of beam B8 loaded at third points was $48.25 \mathrm{kN}$. This shows 
an increment of $23.72 \%$ of the ultimate load of B8 over that of B7. Also for beams B9 and B10 with $25 \mathrm{~mm}$ diameter service holes at the supports but loaded at the centre and at third points respectively, had their ultimate loads to be $52.0 \mathrm{kN}$ and $65.0 \mathrm{kN}$ respectively. This shows that ultimate load of B10 is $25 \%$ greater than that of B9. Table 3 shows the comparative analysis of the estimated load and actual load of the experimental beams. For beams B1 and B2, the estimated ultimate load is greater than the actual ultimate load by $6.62 \%$ and $51.04 \%$ respectively. For beams B3, B4, B5 and B6, the estimated ultimate load is greater than actual ultimate load by $72.21 \%$, $140.25 \%, 16.00 \%$ and $55.18 \%$ respectively. Also for beams B7, B8, B9 and B10, the estimated ultimate load is greater than actual ultimate load by $85.90 \%, 134.78 \%, 39.42 \%$ and $74.28 \%$ respectively. The comparative analysis of the estimated and actual shear capacities of both the control and experimental beams were shown in Table 4. For beams B1 and B2, the percentage increase of the estimated shear capacity over the actual is $168.62 \mathrm{kN}$ and $143.55 \mathrm{kN}$ respectively. For Beams B3, B4, B5 and B6, the percentage increase of the estimated shear capacity over the actual is $333.87 \mathrm{kN}, 287.32 \mathrm{kN}, 192.26$ $\mathrm{kN}$ and $150.22 \mathrm{kN}$ respectively. Also for Beams B7, B8, B9 and $\mathrm{B} 10$, the percentage increase of the estimated shear capacity over the actual is $368.36 \mathrm{kN}$, $278.49 \mathrm{kN}, 251.27 \mathrm{kN}$ and $181.02 \mathrm{kN}$ respectively.

The effect of size of service holes on the strength characteristics of beam loaded at the centre is presented in Table 5. The ultimate load of the control beam loaded at centre is greater than the ultimate load for beams B3 and B7 by $38.09 \%$ and $42.65 \%$ respectively. Also, the percentage increase of the ultimate load of B3 over that of B7 is $7.95 \%$. This indicates that for beams with diameter of service holes at the centre, increases from $20 \mathrm{~mm}$ to $25 \mathrm{~mm}$, there is $7.95 \%$ decrease in ultimate load when loaded at the centre. Also for beams B5 and B9, with $20 \mathrm{~mm}$ and $25 \mathrm{~mm}$ diameter holes at the supports and loaded at centre, the reducing effect of increasing the diameter of the holes from $20 \mathrm{~mm}$ to $25 \mathrm{~mm}$ on the ultimate load is $20.19 \%$.

Table 5: Effect of Size of Hole on Strength Characteristics of Beams

\begin{tabular}{llll}
\hline Beam No & Ultimate Load & $\left(\frac{F_{C O N T B}-F_{E X P B}}{F_{C O N T B}}\right) \times 100 \%$ & $\left(\frac{V_{C O N T B}-V_{E X P B}}{V_{C O N T B}}\right) \times 100 \%$ \\
\hline \multicolumn{4}{l}{ Beams loaded at Centre with Point Load } \\
Ultimate load of control beam B1 $=68.00 \mathrm{kN}$ \\
B3 & 42.10 & 38.09 & \\
B5 & 62.50 & 8.09 & 38.09 \\
B7 & 39.00 & 42.65 & 8.09 \\
B9 & 52.00 & 23.53 & 42.65 \\
Beams loaded at Third Points & 23.53 \\
Ultimate load of control beam B2 & \\
B4 & 47.15 & 37.13 & \\
B6 & 73.00 & 2.67 & 37.13 \\
B8 & 48.25 & 35.67 & 2.67 \\
B10 & 65.00 & 13.33 & 35.67 \\
\hline
\end{tabular}

Table 5 also shows the effect of size of service holes on the strength characteristics of beam loaded at third points. The ultimate load of the control beam loaded at third points is greater than the ultimate load for beams B4 and B8 by $59.07 \%$ and $55.44 \%$ respectively. Also, the percentage increase of the ultimate load of B4 over that of B8 is $2.33 \%$. This indicates that for beams with diameter of service holes at the centre, increase from $20 \mathrm{~mm}$ to $25 \mathrm{~mm}$, there is $2.33 \%$ decrease in ultimate load when loaded at third points. The ultimate load of the control beam loaded at third points is greater than the ultimate loads for beams B6 and B10 by $2.74 \%$ and $15.38 \%$ respectively. Also for beams B6 and B10, with $20 \mathrm{~mm}$ and $25 \mathrm{~mm}$ diameter holes at the supports and loaded at third points, the reducing effect of increasing the diameter of the holes from $20 \mathrm{~mm}$ to $25 \mathrm{~mm}$ on the ultimate load is $12.31 \%$.

Using Eq. 5 (ACI 318, 2008) and Eq. 6 (Olanitori and Afolayan, 2016), the estimated shear capacities are $91.5 \mathrm{kN}$ and $26.57 \mathrm{kN}$ respectively, while the shear force at failure was $37.5 \mathrm{kN}$ and $34.0 \mathrm{kN}$ for the control beams loaded at third points and at the centre with a point load respectively. The shear at failure is less than the predicted value of ACI 318 (2008), because the beams failed by bending before the attainment of their ultimate shear capacities. The value of the estimated shear capacity using Eq. 3 (Olanitori and Afolayan, 2016) is less than the shear force at failure, because the equation was derived from beams with fixed ends.

Conclusion: The ultimate load and shear capacity of beams with service holes depends on the size of holes, position of holes and the type loading. The bigger the diameter of the service holes, the more the reducing effect on the ultimate load. Also, the service hole at the centre of the have higher reducing effect on the ultimate load and shear capacity, when compared with the ones near the supports, hence service holes should be located near the supports of beams, as practicable as possible. 
Acknowledgements: The authors would like to thank the Department of Civil Engineering, Federal University of Technology Akure, Ondo State, and Department of Civil Engineering, Federal Polytechnic, Ado-Ekiti, Ekiti State, for allowing us to use their structural engineering laboratories.

\section{REFERENCES}

American Concrete Institute. (2008). ACI 318-14: Building Code Requirements for Structural Concrete. American Concrete Institute. Michigan, USA.

Arslan, G (2008). Cracking Shear Strength of RC Slender Beams without Stirrups. Journal of Civil Engineering and Management. 14(3): 177-182.

Arslan, G (2012). Diagonal Tension Failure of RC Beams without Stirrups. Journal of Civil Engineering and Management. 18(2): 217-226.

Arslan, G; Polat, Z (2013). Contribution of Concrete to Shear Strength of RC Beams Failing in Shear. Journal of Civil Engineering and Management. 19(3): 400-408.

Aziz, AH (2016). Experimental and Theoretical Evaluation for Effect of Openings Locations on Shear Strength of RC Beams. Journal of Engineering and Development. 20(10): 1 - 15 .

British Standards Institution. (2004). BS EN 1992-11:2004: Design of Concrete Structures, Part 1-1: General Rules and Rules for Buildings. British Standards Institution. London.

British Standards Institution. (2009). BS EN 123905:2009: Testing Hardened Concrete. Part 5: Flexural Strength of Test Specimens. British Standards Institution. London.

Brown, MD; Bayrak, O; Jirsa, JO (2006). Design for Shear Based on Loading Conditions. ACI Structural Journal. 103(4): 541-550.

Khuntia, M; Stojadinovic, B (2001). Shear Strength of Reinforced Concrete Beams without Transverse reinforcement. ACI Structural Journal. 98(5): 648656.

Kim, JK; Park, YD (1996). Prediction of Shear Strength of Reinforced Concrete Beams without Web Reinforcement. ACI Mat. J. 93(3): 213-222.
Kotsovs, MD (2007). Concepts Underlying Reinforced Concrete Design: Time for Reappraisal. ACI Structural Journal. 104(6): 675-684.

Mansur, MA; Tan, KH; Lee, SL (1985). A Design for Reinforced Concrete Beams with Large Openings. Journal of the American Concrete Institute, Proceedings, Vol. 82, No. 4. Pp. 517-524.

Mansur, MA; Tan, KH (1999a). Effects of Creating Opening in Existing Beams. ACI Structural Journal. 98(3): 407-415.

Mansur, MA; Tan, KH (1999b). Concrete Beams with Openings: Analysis and Design. London. Boca Raton, CRC Press.

Mansur, MA; Tan, K.H; Weng, W (2006). Analysis of Concrete Beams with Circular Web Openings using Strut and Tie Models. Malaysian Journal of Civil Engineering. 18(2): 89-98.

Mohamed, AR; Shoukry, MS; Saeed, JM (2014). Prediction of the Behaviour of Reinforced Concrete Deep Beams with Web Openings using the Finite Element Method. Alexandria Engineering Journal. 53(2): 329-339.

Olanitori, LM; Afolayan, JO (2014). Effects of Pit-Sand on Resistance Capacities of Reinforced Concrete Space Framed Structures. Open J.of Civil Engineer. . 4(4): 328-337.

Olanitori, LM; Afolayan, JO; Arum, C (2014). Mode of Collapse of Square Single Panel Reinforced Concrete Space Framed Structures with Beam/Column Joints Hinged. Res. J. Engineer. Appl. Sci. 3(5): 358-365.

Olanitori, LM; Afolayan, JO; Arum, C (2016). Mode of Collapse of Square Single Panel Reinforced Concrete Space-Framed Structures with Rigid Beam-Column Joints. Nig. J. Technol. 35(1): 16-24.

Olanitori, LM; Tifase, TO (2017). Effect of Small Transverse Holes on Flexural Strength of Reinforced Concrete Slender Beams. West Africa Built Environment Research (WABER) Conference, Accra, Ghana, Pp 607-615.

Rebeiz, KS (1999). Shear Strength Prediction for Concrete Member. J. Struct. Engineer.. 125(3): 301308.

Vivek, R; Ch. Madhavi, T (2016). Behaviour of Reinforced Concrete Beam with Web Openings. ARPN J. Engineer. Appl. Sci. 11(9). 5983-5995. 